\title{
A MILESTONE IN SUCESSFUL FRANCHISOR OF MOLY-CARE CAR CARE COMPANY
}

\author{
Arunee Lertkornkitja ${ }^{1}$ and Wari Chokelumlerd ${ }^{2}$ \\ ${ }^{1,2}$ Stamford International University
}

\begin{abstract}
Entrepreneurship and marketing are the interface functions in the corporate responses to an increasingly rivalry and complex external environment. Both concepts illustrate organizational direction toward creativity, innovation, adaptability, and risk-taking. This paper aims to explore strategic successfulness of a Thai corporate embracing franchising as a preferred method for growing its business. Given the exploratory nature of this study, single case study was designed. In-depth interview (face-to-face) with a managing director was conducted. The finding shows a connection between entrepreneurship and marketing as well as the linkage with franchising. The preliminary data has important implication for entrepreneurial marketing, franchising theorists, and practitioners in informing guidelines for the success of business operations in franchising. In addition, this study provides a platform for future study.
\end{abstract}

Keywords: entrepreneurship, marketing, franchising

\section{Introduction}

After establishment of ASEAN Economic Community (AEC) in December 2015, the 10 ASEAN countries are scheduled to form a single market. This will promote the free flow of goods, services, capital and people among members. Thailand has a domestic market of approximately 67 million people but after the AEC this market will effectively increase to about 600 million people, a tremendous chance for Thai enterprises to increase their revenue. Small and medium-sized enterprises (SMEs) play an important role in the world economy and contribute substantially to income, output and employment (The Ediburgh Group, 2012). In Thailand, SMEs are the life blood essential to Thailand's economic vitality. Defined as companies with no more than 200 employees and 200 million baht in assets, SMEs make up $98.5 \%$ of total enterprises in the country, creating jobs for more than 11.78 million people or $89.4 \%$ of the national workforce. SMEs account for $37 \%$ of Thailand's gross domestic product, contributing about US\$140 billion to the GDP (Office of Small and Medium Enterprises Promotion, 2013).

Under the ASEAN Frameworks Agreement on Service (AFAS) among AEC members; franchising is categorized as a deliverable service (Department of Business Development, 2013). Franchising is the most ubiquitous and fastest growing form of cooperative arrangements among entrepreneurs (Gassenheimer, et al., 1996). In international expansion, franchising is one of the most preferred strategies as it provides flexibility and economies of scale to worldwide operations (Contractor \& Kundu, 1998). Hence, this liberation provides an opportunities for Thai franchise to easily expand internationally. With the Thai government strongly committed and actively promoting franchising as one of its strategies in developing local SMEs. Under the newly Thai National Franchise Development Plan 2016, the Thai government hope to 1) create an enterprise to franchise system (B2B franchise), 2) develop a business franchise to meet Franchise Standard, and 3) support a potential franchisor to expand internationally (The Department of Business Development, 2015).

Statistics from Thai Franchise Center shown that in December 2015, there were 482 franchise businesses with approximately 92,000 franchisees, with the total investment of US\$ 2.29 billion. Under service franchise category, there are 41 franchise business or $8.51 \%$ and there is only car care business, Moly Care Car Care. Furthermore, Moly Care Car Care is the only Thailand Franchise Quality Award (TFQA) certified service Thai franchisor from the Department of Business Development, Ministry of 
Commerce. With its 50 domestic franchisees and 6 franchisees in 3 countries, this proves the successfulness of Moly Care Car Care Thai franchisor in domestic and international markets. The purpose of this paper is to explore the strategic successfulness of a Thai corporate embracing franchising, Moly Care Car Care, as a preferred method for growing its business. The paper begins with a brief overview of the company and the findings that link between franchising, entrepreneurships and marketing. The paper, then, concludes with the discussion of the implications of this case for researchers and practitioners.

\section{Literature Review}

\section{Entrepreneurships}

The term "entrepreneurship" has been approached as a characteristic of an innovative, risk taking individual attempting to achieve commercial success with in a new venture. Entrepreneurship can also be conceptualized as a process or activity within the organization, distinct from specific individuals (Morris \& Paul, 1987). Current perspective focus on "the process of creating value by bringing together a unique package of resources to exploit an opportunity". This definition transcends the more narrow perspectives of entrepreneurship as a personality characteristic, or entrepreneurship as the starting of a small business. Approach as a process, the concept has potential applications not just in startup ventures but in organizations of all sizes and types (Davis, et al., 1991).

According to Davis, et al. (1991), the entrepreneurial process appears to have three key dimensions: innovations, risk-taking, and proactiveness (cited in Carland et al., 1984, Drucker, 1985, Kao 1989, Miller \& Friesen, 1983, Morris \& Paul 1987). Innovativeness refers to the seeking of creative, unusual, or novel solutions to problems and needs. This includes the development of new products and services, as well as new processes and technologies for performing organizational functions. The risktaking dimension involves the willingness of management to commit significant resources to opportunities having a reasonable chance of costly failure. Proactiveness, the focus here is implementation, on making events happen through whatever means are necessary. Moreover, the proactiveness dimension implies a "hands-on" management style, where executives work with employees, customers, suppliers, and others to overcome obstacles.

Entrepreneurship is a dynamic goal-oriented process whereby an individual combines creative thinking to identify marketplace needs and new opportunities with the ability to manage, secure resources and adapt to the environment to achieve desired results while assuming some portion of risk for the venture (Smart $\&$ Conant, 2011). Given the turbulence posed by globalization, it is expected that SMEs with an entrepreneurial orientation will fare better than those that lack such an orientation. Here, we proposed

Preposition 1: Successfulness of a franchisor will be positively associated with entrepreneur's innovativeness

Preposition 2: Successfulness of a franchisor will be positively associated with entrepreneur's risk taking

Preposition 3: Successfulness of a franchisor will be positively associated with entrepreneur's proactiveness

\section{Franchising}

Franchising involves a long-term contractual agreement between two types of firms in which a parent company (the franchisor), having developed a product or service, agrees to allow another firm (the franchisee) to sell that product or service under the firm's brand name in a specific way, in a particular location, and during a given period in return for a one-off initial fee and an annual sales-based payment (Combs, et al., 2011, Davies, et al., 2011, Tracy \& Jarvis, 2007). Business format franchise organize that the success of their system is directly influenced by their ability to design and enforce rigid operational standards across their network of retail units (Davies, et al., 2011). Moreover, franchising is a knowledge transfer process and training plays an important role ranging from training programs, pre-opening training, start-up training, manuals supplied, no of pages, etc. (Paynter \& Arthanari, n.d.).

According to Chiou \& Droge (2015), stated that franchising attempts to capitalize on economies of scale and scope, as well as the benefits derived from small, localized operations (cited in Bradach 1997). Both franchisors and franchisees aim to maximize profit (cited in Spinelli \& Birley 1996). Business 
format franchising is also the true locus of franchising entrepreneurship. Moreover, the entrepreneurfranchisor that create these systems must not only risk the resources to develop the concept and operating system, but do so in a manner that permits efficient turnkey transfer to the operating franchisees (Kaufmann \& Dant, 1998). Achieving the franchisor's goal of consistent quality and uniform brand image through standardization (Chiou \& Droge, 2015).

\section{Marketing}

David (2000), stated that marketing concepts are organizational philosophy or culture, as a strategic process, and as a series of tactical functions or methods, all of which required market intelligent (cited in Kohli and Jaworski, 1990).

i) Marketing as an organizational philosophy relates to a set of values and beliefs concerning the central importance of the customer to the success of the organization, which requires that an understanding of customer needs should precede and inform the development and marketing of products and services (Kotler, 1997).

ii) Marketing as a strategy defines how an organization is to complete and survive in the market place. Most marketing textbooks review marketing strategy through the stages of market segmentation, targeting and positioning. This involves firstly, research and analysis of the market place in order to divide it into meaningful groups or segments of buyer-types. Secondly, one or more segments are chosen as the most appropriate targets for marketing activities. Thirdly, an appeal is made to this target group through an appropriately positioned product or service.

iii) Market methods are the specific activities and techniques, such as product development, pricing, advertising and selection of distribution channels, which implement the strategy. These are referred to as elements of the 'marketing mix', commonly summarized as the four 'Ps' of product, price, promotion, and place.

iv) Marketing intelligence underpins each of these marketing principles. The members of a marketingoriented organization undertake information-related activities defined by Kohli and Jaworski (1990: 3) as the 'organization wide generation, dissemination and responsiveness to market intelligence'.

Davis, et al (1991), marketing is concerned with the facilitation of exchange processes between organizations and their environments. The facilitation generally takes the form of marketing mix activities, such as branding, pricing, customer service, advertising, and personal selling.

Thus, entrepreneurial marketing is the organizational function of marketing that embraces the opportunities of the marketplace in terms of an effective implementation of price, promotion, and product tactics (4P's) by being risk-taking, innovative, and proactive (Kraus, et al., 2009).

From the above discussion, we proposed:

Preposition 4: Successfulness of a franchisor will be positively associated with franchisor's brand name

Preposition 5: Successfulness of a franchisor will be positively associated with franchise's operational standards / manual

Preposition 6: Successfulness of a franchisor will be positively associated with training

Preposition 7: Successfulness of a franchisor will be negatively associated with fee and annual payment

Preposition 8: Successfulness of a franchisor will be positively associated with communication

Preposition 9: Successfulness of a franchisor will be positively associated with after sales follow-up

\section{Research conceptual framework}

Figure 1 illustrate the research conceptual framework under which this research would be conducted. 


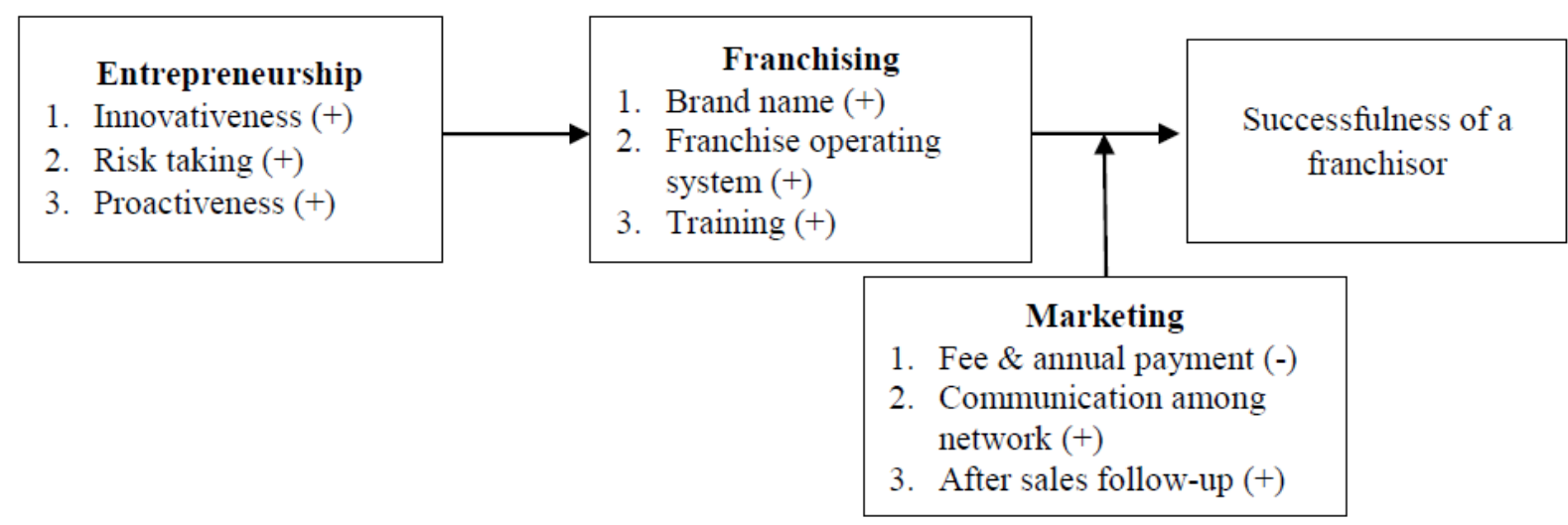

Figure 1: Research conceptual framework

\section{Method}

This study aimed to explore the strategic successfulness of Moly Care Car Care franchise, the only car care franchise business in Thailand with 3 years TFQA certified from Department of Business Development. Qualitative method, a single case analysis, was considered in this study because the research into franchising has been largely quantitative, which makes its complexities very difficult to tracked and study in detail. Moreover, some qualitative franchising researching has been conducted but mainly focus on food franchise. Yin (1994, 2003), a single case study is considered a more appropriate strategy for answering research questions which ask 'how' and 'why' and which not control over the events. Single case can be valuable and a suitable research strategy for theory testing (Yin, 2003). Therefore, the decision of carrying out case study was that they are valuable as preliminaries to major investigations as they generate rich data that may suggest themes for more intensive investigation (Choo, 2003).

Multiple sources, in-depth interview, documents research, and observation, were used to collect data and providing the triangulation in this study. Faceto-face in-depth interview with the managing director who directly involve in business strategies was extensively used to collect data. The typical interview lasted two and a half hour, then follow by company visit. The interview was tape-recorded and transcribed to identify the strategic successfulness of this franchise. After that, the method of qualitative analysis draws on Yin (1994)'s preferred strategy of relying on theoretical proposition that led to the case study. The propositions helped to organize the case study and examine alternative explanations. Drawing conclusions and verifying them took place before, during, and after data collection.

The Moly Care Car Care case summary

Starting, in 1981, from Car-Lack which was a joint venture between Thai and German to market car care products. In 2000, Mr. Krit Karnchanabatr was appointed to be in charge of the company as a General Manager. After a market and consumer behavior surveys had been conducted, he realized that how many cars were on the road in Thailand and how car care services were needed by car users. Therefore, a car care service franchise Car-Lack 68 was launched in 2003, providing washing program, exterior and interior cleaning, polishing, coating, and anti-rust programs. In order to grow not only domestic but also international market, a market testing was needed to ensure the successfulness in the first move. Hence, Moly Care by Car-68 was founded as a Thai own company in 2007 with the brand new concept and design. In 2015, there were more than 50 franchisees in Thailand and has been expanding into 3 countries in ASEAN - Myanmar, Laos and Cambodia. The achievement awards received clearly prove its success. For instance, Thailand Franchise Quality Award in the year 20112013 and so forth. 


\section{Findings and Discussion}

\section{Entrepreneurial Orientation}

The executive of Moly Care Car Care's traits were found related to entrepreneurship. These included having a somewhat better education, coming from family where the parents owned a business, working in areas related to what they had done before (Smart \& Conant, 2011). Furthermore, the findings shown that the organization executive's entrepreneurship innovative, risk taking and proactiveness were positively associated with the successfulness of the franchisor. These results supported our propositions. As we found and analyzed from the interview; "We started Car Lack 68 franchise with a very limitation of knowledge about franchising but we see the opportunity." "... our initial franchise fee was set at US\$1,300, we sold 13 franchise a year which was not bad. However, after that we found so many problems. The problem was we had started franchising without the clear understanding of this business format. Thus, I took franchising, entrepreneur, SMEs courses." "We continuously develop and introduce a new service for our franchisees - Moly Crystal." “... to strengthen our brand name, the new design - Moly Care Extreme will be launched in the very near future to capture the hi-end segment."

These findings were in line with Falbe \& Welsh (1988) franchisor's perception toward success positively affects action, organization performance, and franchise success. The natural bond between marketing and entrepreneurship may be value creation. Five categories of behavior that identified an entrepreneurial venture; 1) introduction of new goods; 2) introduction of new methods of production; 3) opening of new markets; 4) opening of new sources of supply; 5) industrial reorganization; and 6) the introduction of new services (Smart \& Conant, 2011). Risk taking reflects the propensity to devote resources to projects that entail a substantial possibility of failure, along with the chances for high returns (Knight, 2000).

\section{Franchising}

Franchise operating system, training, and brand name (a factor that included the quality of the operating system) were rated as the key determinants of the franchise's success. These findings supported our propositions.

Franchise operating systems are the most important type of contractually linked vertical marketing systems. One of the key issues in franchising is designing contractual mechanisms (or standards) to control franchisee opportunism (Chiou \& Droge, 2015). A business operating system or franchise operational manual is the company's unique way of doing things - how it operates, goes to market, produces and deals with its customers. An effective business operating system transcends the people who are doing and managing the work, and is more valuable as a result. A business that effectively operates without you is always more attractive to public and private sources of capital (Colan, 2015). "I wondered how and why the giant franchisors like McDonald, Pizza Huts are so successful expanding globally. One day, I attended an exhibition about franchising and met up with Francorp, a consulting firm. I decided to appoint this firm to develop a system operating system for us.” “... our operation manual provides the daily, weekly and monthly processes, systems, roles of franchisor and franchisee, how to select, recruit, and hire the employees, basic account, structure, etc."

When the franchisees sign the franchise agreement, training plays an important role ranging from training programs, pre-opening training, start-up training; "franchisees (both domestic and international) must come to head quarter for training, they must try washing the cars themselves, of course". Overall franchise performance is strongly dependent upon the disciplined and unproblematic coordination between franchisor and franchisees, as this operational diligence is necessary for maximizing brand value, ensuring consistency in product and service output, and most fully capitalizing upon management support (Davies, et al., 2011).

Organizational brands are an integral part of a firm's marketing strategy and are valuable sources of differentiation. The value of a franchise system's brand is largely dependent upon the franchisor's ability to enforce contractual provisions that encourage the maintenance of uniform product and 
service standard (Weaven \& Frazer 2007). Especially, the franchise companies with wellknown or prestigious brand name gain a reputation for quality and profits for the overall franchise network, which increase the number of candidates willing to become its franchisees (Baena \& Cervino n.d.). The interview found that; "We spent our resources and time to develop and strengthen our brand name by employing a consultant to create the new concept, brand and design."

\section{Entrepreneurial Marketing}

Price bonding or initial franchisee fee and annual payment, from this study, was found not supported our preposition. "... after rebranding and increase the franchise fee, we can sell more franchise. "Franchising is not just try to sell the low initial franchise fee but we sell the experience, quality operation system and services. That is why we invest in brand building".

Communication among network and after sales follow up were supported our prepositions, positively associated with the successfulness of franchisor. Franchising involves both franchisor and franchisee relationship through the franchise contract which the franchisor specifies the responsibilities of each partner and how the assets and economic rewards are distributed. Conflict between two parties are likely to emerge if the priorities, timing, and revenue streams between franchisor and franchisee are overlapping (Davies, et al., 2011). Communication improves relations and performance of the franchise system while enhancing franchisees' freedom to act on entrepreneurial tendencies and advance their own business ventures (Paynter \& Arthanari, n.d.).

"We use social media; facebook and LINE as an effective network communication tools. Special meeting with franchisees was held from time to time." "... when they (franchisees) call, you have to go. I believe, having a well-structured organization - sales, marketing, training teams, and the administrative teams to support our franchisees and growth are crucial. You cannot work alone."

These conform Davies, et al. (2011) that conflict that can be resolved through communication that accommodates feelings and motives between each party is more likely to achieve the perceived realignment of interests, values, and norms, thus strengthening trust. These aligned values and interests among all entrepreneurs within a franchise system will subsequently result in greater brand consistency, and thus overall franchise value (Davies, et al., 2011).

\section{Implication, Limitation and Future Research}

This study represents advances in entrepreneurial franchising knowledge. Specially, it contributes to practitioners in which the firm can incorporate the concept of franchising as a preferred method for growing their business. In term of academic contribution, our research demonstrates conceptually through the entrepreneurship, franchising and marketing concepts vital for a successful franchisor. Specifically, we reveal the importance of domain of entrepreneurship who discover and exploit market opportunities. Franchising, as a process, is a unique form of business collaboration between multiple entrepreneurs - franchisor and franchisee. It is our hope that both entrepreneurship scholars and franchising scholars will see this benefits of this intersection.

Limitations of this study were; first, this study acknowledges the quality of the data which was drawn from only one franchisor. Second, this study examined from the perspective of franchisor only. Therefore, the future research that build on the present study should broaden the data collection from many different franchises in various categories in order to compare and generalize the research finding. There is a further need for franchisee's perspective approach that would identify gaps the successful of a franchisor. Future research might also involve introducing additional variables into the model that may affect the successful of franchising. Finally, one might investigate, the quantitative research is needed to quantify the finding and reveal the relationship of each variable to the successful of franchise.

\section{References}

Chiou, J.-S. \& Droge, C., 2015. The effects of standardization and trust on franshisee's performance and satisfaction: A study on franchise system in the 
growth stage. Journal of Small Business Management, 53(1), 129-144.

Espace Library Curtin University, Determining the critical success factors of international franchising: cases of foreign franchisors in East Asia, Date of access: $20 / 1 / 2016$

http://espace.library.curtin.edu.au/R/?func=dbinjump-full\&object_id=19691\&local_base=GEN01ERA02

INC, How to successfully build a business operation for yout company, Date of access: 15/3/2016. http://www.inc.com/lee-colan/building-your-

business-operating-system.html.

Combs, J. G., David J. Ketchen, J. \& Short, J. C., 2011. Franchising reseach: major milestones, new directions, and its future within entrepreneurship. Entrepreneurship Theory and Practice, May, 413-425.

Contractor, F. \& Kundu, 1998. Model Choice in a world of alliances: Analyzing organizational forms in the international hotel sector. Journal of International Business Studies, 29, 325-358.

Davies, M. A., Manolis, W. L. C., Prince, M. \& Winsor, R. D., 2011. A model of trust and compliance in franchise relationships. Journal of Business Venturing, 26, 321-340.

Davis, D., Morris, M. \& Allen, J., 1991. Perceived environmental turbulence and its effect on selected entrepreneurship, marketing and organizational characteristics in industrial firms. Journal of the Academy of Marketing Science, 19(1), 43-51.

Department Of Business Development, 2013. Research paper on franchise marketing strategy. (Bangkok).

Gassenheimer, J. B., Baucus, D. B. \& Baucus, M. S., 1996. Cooperative arrangements among ntrepreneurs: An analysis of opportunism and communication in franchise structures. Journal of Business Research, $36,67-79$

Kaufmann, P. J. \& Dant, R. P., 1998. Franchising and the domain of entrepreneurship research. Journal of Business Ventruing, 14, 5-16.

Knight, G., 2000. Entrepreneutship and marketing strategy: The SME under globalization. Journal of International Marketing, 8(2), 12-32.

Kraus, S., Harms, R. \& Fink, M., 2009. Entrepreneurial marketing: Moving beyond marketing in new ventures. Int. J. Entrepreneurship and Innovation Management, Issue Special Issue.
Morris, M. H. \& Paul, G. W., 1987. The relationship between entrepreneurship and marketing in established firms. Journal of Business Venturing, 2, 247-259.

Office of Small and Medium Enterprises Promotion, 2013. AEC+6 White paper on SMEs 2013, Thailand: s.n.

Paynter, J. \& Arthanari, T., Determinants for franchise success. Date of access: 26/1/2016. http://orsnz.org.nz/conf36/papers/Paynter.pdf.

Smart, D. T. \& Conant, J. S., 2011. Entrepreneurial orientation, distinctive marketing competencies and organizational performance. Journal of Applied Business Research , 10(3), 28-38.

Thai Franchise Center, Statistic of Thai Franchise in Thailand, Date of access: 16/2/2016. http://www.thaifranchisecenter.com/stats/franchise_st ats.php?year=2015.

DBD. The Department of Business Development. Date of access: 16/2/2016. http://www.dbd.go.th/ewt_news.php?nid=5207.

The Ediburge Group, 2012. Growing the global economy through SMEs. (Ediburgh Group).

Tracey, P. \& Jarvis, O., 2007. Toward a theory of social venture franchising. Entreprenejrship Theory and Practice, September, 667-685.

Yin, R. K., 1994. Case study research design and methods. 2nd ed. (California: Sage Publications, Inc.).

Yin, R. K., 2003. Case study research: Design and methods. 3rd ed. (California: Sage Publications, Inc.). 